\title{
Design for Manufacture and Assembly (DfMA) in construction: the old and the new
}

Weisheng $\mathrm{Lu}^{1}$, Tan Tan ${ }^{2 *}$, Jinying $\mathrm{Xu}^{3}$, Jing Wang ${ }^{4}, \mathrm{Ke} \mathrm{Chen}^{5}$, Shang $\mathrm{Gao}^{6}$, and Fan Xue ${ }^{7}$

This is a copy of the peer-reviewed Accepted Manuscript of the paper:
Lu, W., Tan, T., Xu, J., Wang, J., Chen, K., Gao, S. \& Xue, F. (2020). Design for
Manufacture and Assembly (DfMA) in construction: The old and the new.
Architectural Engineering and Design Management, in press. Doi:
$\underline{10.1080 / 17452007.2020 .1768505}$
This document is available for personal and non-commercial use only, as permitted by
Taylor \& Francis Group's Architectural Engineering and Design Management. The final
version is available online: http://www.tandfonline.com/10.1080/17452007.2020.1768505

\begin{abstract}
Design for manufacture and assembly (DfMA) has become a buzzword amid the global resurgence of prefabrication and construction industrialization. Some argued that DfMA is hardly new, as there are concepts such as buildability, lean construction, value management, and integrated project delivery in place already. Others believe that DfMA is a new direction to future construction. This paper aims to review the development of DfMA in manufacturing and its status quo in construction, and clarify its similarities and differences to other concepts. A multi-step research method is adopted in this study: First, an analytical framework is generated; Secondly, a literature review is conducted on DfMA in general, and DfMA-like concepts in the AEC industry; The third step is to compare DfMA with related concepts. This study reveals that DfMA as a philosophy is hardly new in construction, and the empirical implementation of many DfMA guidelines has begun in the AEC industry. The findings suggested that DfMA is a new and mixed 'cocktail' of opportunities and challenges to improve construction productivity with the advancement of construction materials, production and assembly technologies, and ever-strengthened logistics and supply chain management. This study sheds light on three research directions: DfMA implementation and guidance strategies, DfMA frameworks and blueprints, and applications in cast in-situ or intermediate prefabrication construction. Our research findings provide a synopsis of DfMA research and development in construction. This paper can also serve as a point of departure for future theoretical and empirical explorations.
\end{abstract}

Keywords: Design for manufacture and assembly; Construction Industrialization; Prefabrication; Construction

\footnotetext{
${ }^{1}$ Professor, Department of Real Estate and Construction, The University of Hong Kong, Hong Kong, e-mail: wilsonlu@hku.hk;

${ }^{2}$ PhD Student, Corresponding Author, The Bartlett School of Construction \& Project Management, University College London, London, e-mail: tan.tan.17@ucl.ac.uk, Tel.: +44(0) 771614 8651;

${ }^{3}$ PhD Candidate, Department of Real Estate and Construction, The University of Hong Kong, Hong Kong, e-mail: jinyingxu@,connect.hku.hk;

${ }^{4} \mathrm{PhD}$ Candidate, Department of Real Estate and Construction, The University of Hong Kong, Hong Kong, e-mail: jingww@,connect.hku.hk;

${ }^{5}$ Associate Professor, Department of Construction Management, Huazhong University of Science and Technology, e-mail: chenkecm@hust.edu.cn;

${ }^{6}$ Lecturer, Faculty of Architecture, Building and Planning, The University of Melbourne, Australia, e-mail: shang.gao@unimelb.edu.au;

${ }^{7}$ Assistant Professor, Department of Real Estate and Construction, The University of Hong Kong, Hong Kong, e-mail: xuef@hku.hk;
} 


\section{INTRODUCTION}

Design for manufacture and assembly (DfMA) is an emerging approach in the global architecture, engineering, and construction (AEC) landscape. In 2013, the Royal Institute of British Architects (RIBA) published a Plan of Work for DfMA implementation. In 2016, Singapore's Building and Construction Authority (BCA) issued an official guide facilitating DfMA and its incorporation with Building Information Modeling (BIM). In 2018, the UK government's Infrastructure and Projects Authority published a revised National Infrastructure and Construction Pipeline detailing its preference for the Platform Method for Manufacturing and Assembly Design. The report also publicized its use for prefabrication and other offsite construction methods in public projects. The Hong Kong government's 2018 document Construction 2.0 also emphasises the importance of DfMA. In the research realm, the DfMA literature is growing, while industry leaders such as O'Rourke (2013) and Balfour Beatty (2018) consider DfMA to be the future of construction.

But is DfMA merely old wine in a new bottle? According to Boothroyd (2005), DfMA evaluates and improves product design by considering the downstream processes of manufacturing and assembly. Similar if not identical concepts have been introduced to improve AEC productivity and efficiency. For example, buildability assesses designs from the perspective of those who will manufacture and install components and carry out the construction work (Lam and Wong, 2009); lean construction adapts the concept of lean production/manufacturing to the AEC industry with a view to maximising value and minimizing waste (Koskela, 1992; Alarcón, 1997). Value management (VM) focuses on the early design stage and advocates achieving value for money by deliberating over functions and costs (Kelly et al., 2004; Shen and Liu, 2004), with downstream manufacturing and assembly within the critical scope of the exercise.

This paper aims to clarify the concept of DfMA in the AEC industry. First, we review the literature on its history in the manufacturing industry and current DfMA developments in construction. The research then goes on to compare DfMA with the concepts mentioned above to find their similarities and differences. Based on the review and comparisons, this study further provides prospects and challenges for DfMA. The remainder of the paper is organized as follows. Section 2 is a detailed description of the research methodology. Section 3 is an indepth analysis of the DfMA research, while Section 4 compares DfMA with similar concepts with a view to answering the key question of this study. Section 5 articulates the prospects and challenges of DfMA, while conclusions are presented in Section 6.

\section{METHODOLOGY}

A multi-step research method consisting of brainstorming, literature review and in-depth comparative analyses is adopted in this study. First, given the long history of DfMA development, an analytical framework is required to demarcate a reasonable research boundary and guide the analyses. Since DfMA has only recently been popularized in construction, this research includes DfMA-like construction concepts (e.g., fabrication-aware design) to allow it to be fully investigated. Brainstorming, as a creative training method, can find a set of practical solutions through objective and continuous analysis of the issues discussed (Rawlinson, 2017). To establish the analytical framework for this study, an hour-long brainstorming session was held. Six researchers from different disciplines participated, all with at least six years' research experience in the AEC industry and two with around 10 years' experience in engaging with construction prefabrication in China and Hong Kong. Taking into account the possible bias of brainstorming, this step is only used to determine the scope of the discussion without having a conclusive effect on the outcome of the discussion. As a result of the session, the scope of the study was limited to seven broad DfMA-related categories: origins, definition, processes, 
guidelines, comparisons, prospects, and challenges. The analytic framework developed is shown in Figure 1.

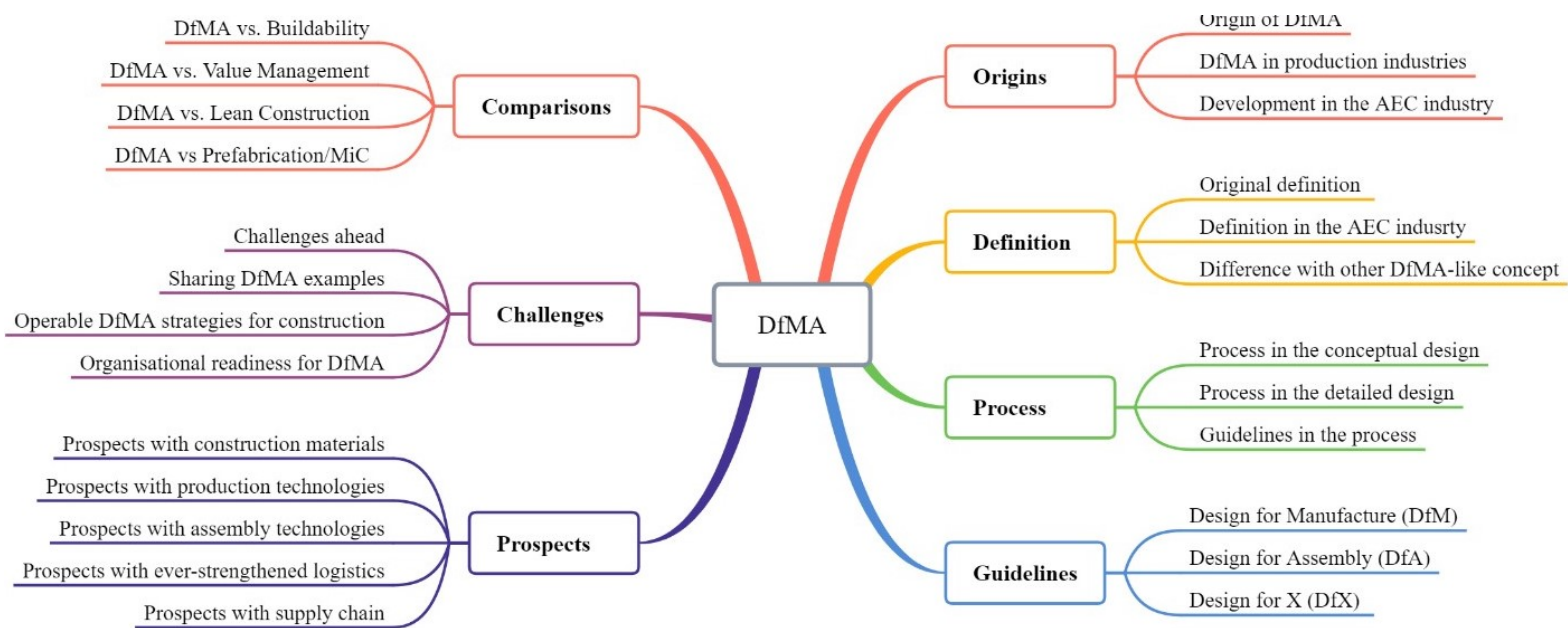

Figure 1 DfMA in construction: an analytic framework

Second, guided by this framework, a search was conducted for the relevant literature on DfMA in general, as well as DfMA-like concepts in the AEC industry specifically, using the bibliographic database Google Scholar. Keywords used in article selection included 'design for manufacture and assembly', 'design for manufacture', 'design for assembly', 'DfMA', 'fabrication-aware design', 'architectural geometry', 'architectural design', 'construction', 'assembly', 'construction industry', and 'AEC'. These keywords were adopted to reflect usages across research disciplines and countries. For example, architecture researchers prefer 'fabrication', while in engineering 'manufacture' is used to describe the building production process. Mathematicians try to use architectural geometry to bridge the gap between complex architectural design and applicable construction. Year of publication was limited to the period 2009 to 2019 to capture the latest DfMA research and trends in AEC. A total of 1979 results were generated from the initial search. Then, the strict filtered process was conducted to narrow down the scope of target articles. Articles that included related key terms in the title/summary/keyword were considered for review, and only journal articles were selected to ensure that all retrieved articles could be analyzed by using the same analytical structure as their research objectives and methods. A snowball technique (Lecy and Beatty, 2012) involving checking the references of the selected papers was applied to find relevant papers that may not have been included. Finally, 30 publications highly related to the DfMA in the construction were derived for the analysis of DfMA definition and research trend.

The third step was to develop an in-depth understanding of DfMA by comparing it with similar concepts, such as buildability, value management, lean construction and prefabrication/Modular integrated Construction (MiC). The literature on these concepts was extracted and reviewed for the comparative study which mainly focused on the connotations, extensions, and applications of the concepts and DfMA and analyzed their similarities, differences, and linkages. These comparisons were triangulated with the past experience of the authors involved in BIM and offsite construction in Hong Kong, China, and the UK.

\section{DFMA: HISTORICAL DEVELOPMENT AND STATUS QUO}

\subsection{Historical development of DfMA}

DfMA originated during World War II when Ford and Chrysler applied it as a principle in their weapon production processes. At first, it was used in manufacturing industry. Formal approaches to design for manufacture (DfM) and design for assembly (DfA) emerged in the 
late 1960s and early 1970s, reflected in UK standards published in 1975 on the management of design for economic production. The academic exploration of DfMA also began in the 1970s with the practice and research of Boothroyd and Dewhurst. Since then, there has been much development of DfMA within the manufacturing industry.

According to Boothroyd (2005), DfMA provides a methodology for evaluating and improving product design by considering the downstream processes of manufacturing and assembly. It thereby signifies a shift from traditional, sequential design thinking to a non-linear methodology. The implementation of DfA and DfM has the potential to bring considerable benefits, including reducing assembly and manufacturing costs, improving quality, and shortening production time by simplifying products. But these are only considerations of production efficiency. Due to the requirements of sustainability, some scholars have begun to consider the consideration of disassembly and recycling during the design phase. Researchers are beginning to focus on the design of the environment, recyclability, life cycle, etc. These studies are sometimes referred to as Design for excellence (DfX) (Kuo et al., 2001). DfX is a related methodology, where the ' $\mathrm{X}$ ' refers to excellence in aspects including testability, compliance, reliability, manufacturability, inspection (DfI), variability (DfV), and cost (DfC). DfX in general aims to provide a standard philosophy, methodologies, and tools to optimize a design (Gatenby and Foo, 1990; Kuo et al., 2001; Eastman, 2012). For example, DfX techniques can improve quality, efficiency, productivity and design flexibility, and decrease life-cycle costs using concurrent design concepts (Maskell 1991). DfX research emphasizes the consideration of all design goals and related constraints in the early design stage (Kuo et al., 2001). Huang (2012) describes two streams of ' $X$ ', one with emphasis on a particular business process and the other on a performance metric. DfA falls into the former since it focuses on the assembly process while using multiple performance measures (inspectability, compatibility, recyclability, serviceability, etc.). Design for modularity, on the other hand, is an example of the latter since it looks into modularity across several business processes from manufacturing to assembly, installation, distribution, and operation. DfMA falls into the business process stream, while both the manufacturing and the assembly processes serve as focal issues. Since the late 1990s, hundreds of papers have been published on the application of DfX in manufacturing. However, this phenomenon has not happened in the construction industry. This makes it difficult to find all the information needed to apply DfX in the construction industry.

\subsection{DfMA processes and guidelines}

Researchers such as Swift and Brown (2013), Bogue (2012), and Emmatty and Sarmah (2012) have developed some guidelines for the application of DfMA, as shown in Table 1. It is a systematic procedure that helps companies make the fullest use of manufacturing and assembly processes, e.g., through emphasizing the ease of manufacture and assembly by minimizing the number of parts (Kuo et al., 2001; Eastman, 2012; Bogue, 2012). DfMA aims to determine the cost impact of those materials and processes, and finds the most efficient use of the component design (Ashley, 1995).

Table 1. A non-exhaustive list of DfMA guidelines

\begin{tabular}{lll}
\hline & Guidelines & Benefits \\
\hline 1 & Aim for mistake-proof design & $\begin{array}{l}\text { Avoid unnecessary re-work, improve quality, and reduce time and } \\
\text { costs. }\end{array}$ \\
2 & $\begin{array}{l}\text { Design for ease of fabrication } \\
\text { Reduce time and costs by eliminating complex fixtures and tooling. } \\
3\end{array}$ & $\begin{array}{l}\text { Design for simple part } \\
\text { orientation and handling }\end{array}$ \\
$\begin{array}{l}\text { Design with predetermined } \\
\text { assembly techniques in mind }\end{array}$ & Reduce time and costs when assembling.
\end{tabular}


5 Consider modular designs

6 Consider design for mechanized or automated assembly

7 Use standard and off-the-shelf components

8 Use as similar materials as possible

9 Use as environmentally friendly materials as possible

10 Minimize precast component types

11 Minimize connector types and quantity

12 Minimize the use of fragile parts

13 Do not over-specify tolerances or surface finish
Reduce time and costs due to simplified design and assembly. Improve assembly efficiency, quality and security.

Reduce purchasing lead time and costs.

Reduce time with fewer manufacture processes and simplified jointing.

Reduce harm to the environment.

Reduce time and costs with simplified design, manufacture, and assembly.

Reduce time and costs with simplified design, manufacture, assembly, repair and maintenance.

Reduce costs due to fewer part failures, and easier handling and assembly.

Reduce costs with easier manufacture.

Sources: Swift and Brown (2013); Bogue (2012); and Emmatty and Sarmah (2012)

However, current DfMA practices in construction still, by and large, follow DfMA guidelines developed in a manufacturing context without sufficiently considering the differences between construction and manufacturing. For example, DfMA procedures in Boothroyd (2005) consider DfA and DfM but not the downstream logistics and supply chain (LSC), which plays a critical role in offsite prefabrication construction. Some construction DfMA guidelines proposed, e.g., Gbadamosi et al., (2019), Kim et al., (2016), and Banks et al. (2018), originate more or less from manufacturing-oriented guidelines. While inspiring, some of these guidelines are not necessarily a good fit with construction's characteristics, leading to an inability to improve manufacturing and assembly. Some guidelines are proposed in a fragmented fashion without necessarily forming an organic whole, leading to a lack of comprehensiveness, or "easy to use" throughout the building process. The RIBA, in recognizing the potential of DfMA in construction, added an overlay of DfMA to its time-honored Plan of Work. Following RIBA's vision (2013, p. 24), much “soft-landing" work remains to implement DfMA in construction.

Connecting general DfMA guidelines (Table 1) with the heterogeneities of the AEC industry to develop DfMA examples could inspire and encourage practitioners. Our stakeholder engagement with the industry has revealed that practitioners including clients, designers, contractors, and suppliers do explore such examples from the perspective of their separate companies. An industry-wide database of DfMA examples could increase its application. Another observation from the literature analysis and industry engagement is that we need to develop DfMA strategies operable in terms of scope, policy, procedure, and so on at company, even industry, level. RIBA's plan of work and various published DfMA blueprints are certainly meaningful points of departure. To embrace DfMA, individual companies need to work with researchers to devise such operable strategies. Frameworks and guidelines that can link general guidelines with company-specific requirements are highly desired.

\subsection{Cross-sectoral learning}

When looking at the history of DfMA in construction, scholars often cite the pioneering modernist architect Le Corbusier who, in his influential book Towards a New Architecture (1923), advocated industrialization of construction and proposed the famous maxim, 'A house is a machine to live in.' However, the popularity of DfMA in construction is a recent 
phenomenon. Unlike manufactured products which are designed in-house, mass-produced, and sold to end users, construction products (e.g., housing, buildings, and infrastructure) are bespoke (Fox et al., 2001). Every construction product is contextualized within the geotechnical conditions of the site and its surroundings, the planned socio-economic function, and many other factors. There can be no 'standard', 'one-size-fit-for-all' design for mass production. It would be exceedingly difficult if not impossible for an architect, like his/her counterparts in manufacturing, to conceptualize, optimize, prototype, and select a design to mass construct. In addition, the orthodoxy dislikes the tedium of 'standard' architecture design. Thus, the 'oneoff' project as an organization form has been adopted in the construction industry to organize works (Wang et al., 2018). Put simply, the construction industry looks at projects while other industries are concerned with products.

While construction materializes our built environment and is linked to cultural identity and civic pride (Pearce, 2003), it has long been criticized for e.g., its nuisance, poor quality (Baloi and Price, 2003), and recently, alleged low productivity (The Economist, 2017). Crosssectoral learning has been exhorted for construction (Kao et al., 2009) but the authors of this paper incline to attribute the learning to the industry's self-introspection and humble characteristics. The construction industry has been reinventing itself through production theory (Koskela 1992), especially through integration of design, manufacture, and assembly (Bridgewater, 1993) and lean concepts and tools for making site assembly more efficient (Tommelein, 1998). In the 2010s, government and industry documents began to include DfMA in their development plans and to illustrate its detailed definition and application in the industry. In these plans, DfMA is advocated to combine architectural design, manufacturing and on-site installation organically. The introduction of DfMA to construction industry can be understood against this cross-sectoral learning and transformation background.

\subsection{Status quo of DfMA in construction}

The Sankey diagram shown in Figure 2 illustrates some of the research trends relating to DfMA in construction drawn from the 30 selected articles. The width of the arrows is proportional to the flow rate. The volume of this research has gradually increased over the past decade. Regarding research trends, architectural design journals tend to focus on the conceptual design stage, while engineering and construction journals focus more on the detailed design phase or the entire project life cycle. There are more articles on DfM than DfA. This may be because all types of construction involve a manufacturing process. However, assembly problems often occur in prefabricated buildings. In some architectural practices that do not fully adopt prefabrication, the idea of DfMA is nonetheless used. So although prefabrication, offsite construction, and MiC provide ideal scenarios in which to explore DfMA (Yuan et al., 2018), its applications are not constrained to these areas. DfMA can be applied in traditional cast insitu construction. It can even be implemented as part of an on-site construction design or offsite prefabricated design (Lu et al., 2018). The degree of implementation may be the entire building, an apartment, or just a component, reflecting the emphasis of DfMA on consideration of downstream processes in order to minimize costs and maximize overall value. 


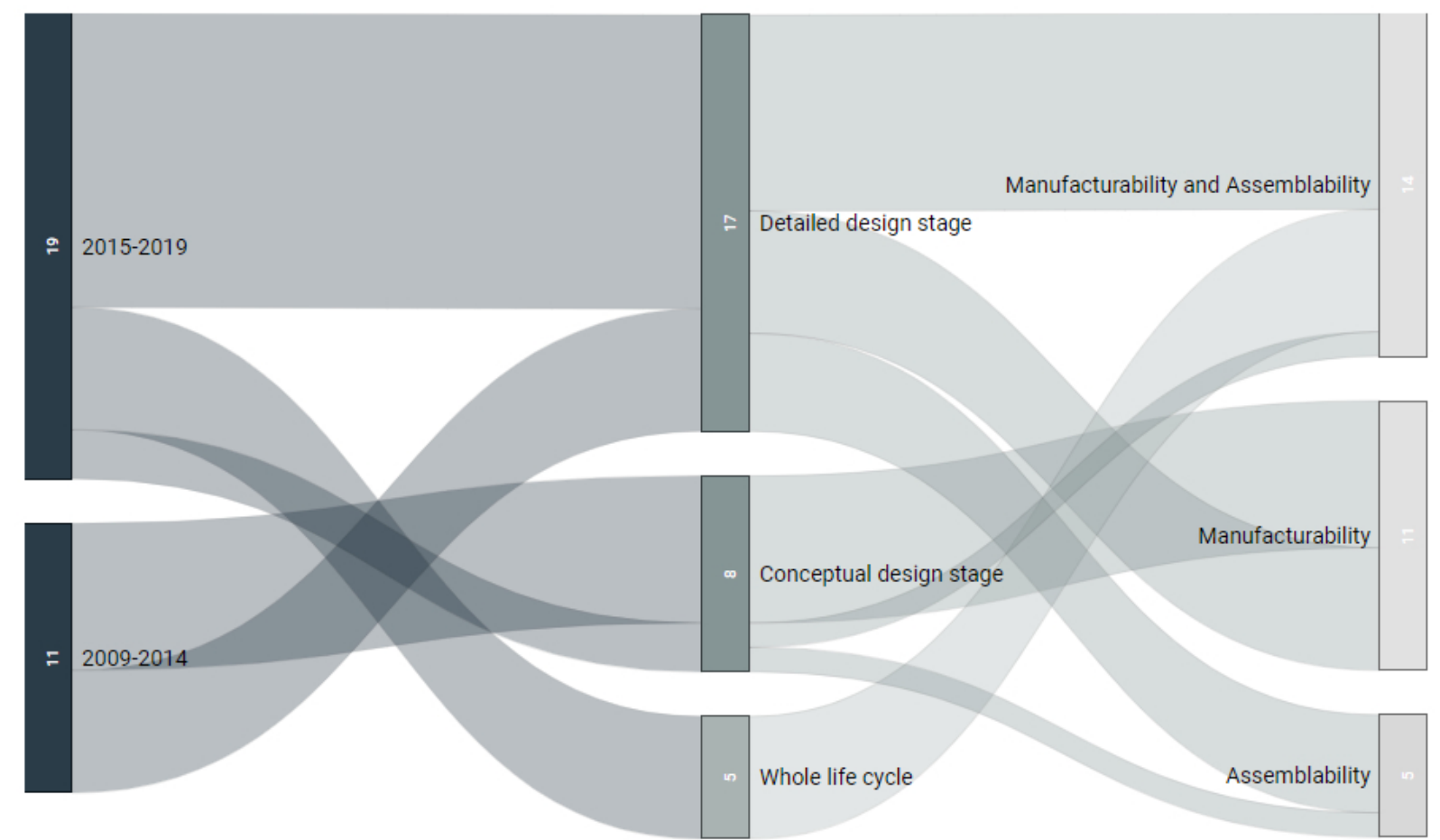

Figure 2 Sankey diagram of DfMA research in the AEC industry

A few empirical studies have begun to investigate the implementation of DfMA, mainly in offsite prefabrication and modular construction projects. As summarized in Table 2, DfMA principles have been applied to various types of construction projects for various components. For example, Kim et al. (2016) reported the use of DfMA in the selection of suitable precast beams for a highway bridge in the UK; Gerth et al. (2013) reported its application in detailing the design of light walls for two four-story houses in Sweden. These studies reveal common practices in applying DfMA, such as identifying its driver, developing criteria for 'manufacturability' and 'assemblability', investigating specific difficulties to address in design, involving different professionals in the design group, and optimizing design through various principles.

Table 2. A summary of construction projects applying DfMA principles

\begin{tabular}{|c|c|c|c|}
\hline Studies & Project type & Related components & DfMA strategies \\
\hline Gerth et al. (2013) & four-storey houses & light wall & $\begin{array}{l}\text { - detail the joint design } \\
\text { - minimize assembly operation }\end{array}$ \\
\hline Kim et al. (2016) & highway bridge & precast beam & $\begin{array}{l}\text { - minimize the number of parts } \\
\text { - simplify the operation } \\
\text { - choose material and components }\end{array}$ \\
\hline Chen and $\mathrm{Lu}$ (2018) & $\begin{array}{l}\text { high-rise } \\
\text { commercial } \\
\text { building }\end{array}$ & curtain wall system & $\begin{array}{l}\text { - coordinate the design of LED } \\
\text { tubes and electric wires in the } \\
\text { curtain wall system }\end{array}$ \\
\hline Banks et al. (2018) & $\begin{array}{l}\text { high-rise } \\
\text { residential and } \\
\text { commercial tower }\end{array}$ & $\begin{array}{l}\text { modularized facade, } \\
\text { MEP system, } \\
\text { structure, etc. }\end{array}$ & $\begin{array}{l}\text { - coordinate the facade, MEP } \\
\text { system, and structure }\end{array}$ \\
\hline $\begin{array}{l}\text { Peterseim et al. } \\
(2016)\end{array}$ & new solar tower & $\begin{array}{l}\text { modules of cable- } \\
\text { stayed solar tower }\end{array}$ & $\begin{array}{l}\text { - select optimal components and } \\
\text { materials }\end{array}$ \\
\hline Ramaji et al. (2017) & student dormitory & modules & $\begin{array}{l}\text { - optimize the size and geometry of } \\
\text { parts }\end{array}$ \\
\hline $\begin{array}{l}\text { Machado et al., } \\
(2016)\end{array}$ & $\begin{array}{l}\text { student } \\
\text { accommodation }\end{array}$ & $\begin{array}{l}\text { fittings } \\
\text { furnishings }\end{array}$ & $\begin{array}{l}\text { - implement BIM as a catalyst for a } \\
\text { lean transformation, streamlining } \\
\text { process and operations }\end{array}$ \\
\hline
\end{tabular}


Previous studies have suggested different strategies for implementing DfMA, such as detailed design, minimization/simplification, and design evaluation. Detailed design entails careful planning to pre-empt issues in the manufacture and assembly stages through choice of materials/components (Kim et al, 2016), integrating different disciplines in design, such as coordinating the modular structure, façade, and mechanical, electrical and pumping (MEP) system in a high-rise building (Banks et al., 2018), or designing the LED tubing and electric wiring for a curtain wall system (Chen and $\mathrm{Lu}, 2018$ ). Minimization/simplification emphasizes ease of manufacture and assembly through minimizing the number of parts (Kim, et al., 2016), simplifying the geometry and reducing weights of parts (Ramaji, 2017), or decreasing complexity in operations (Gerth, 2013). These strategies can directly reduce cost, time, and waste in both manufacture and assembly. In addition, evaluating engineering choices and design alternatives is also a main strategy of DfMA. Significant in this state of the art review is DfMA use for building façades (Montali et al., 2018; Montali et al., 2019; Giuda et al., 2019; Başarır and Altun, 2018), weatherproof seals (Orlowski et al., 2018), and modular components (Rausch et al., 2016). Few studies focus on design optimization of the whole built project, although some such as Yuan et al., (2018) have established a process information model for DfMA-oriented prefabricated buildings. Apart from these studies mentioned DfMA in their research, some DfMA-like concepts were studied for the improvement of manufacturability and assemblability by focusing on the design stage. For example, many studies in architecture use fabrication-aware design to represent the same idea of DfMA. Pottmann $(2009 ; 2010 ; 2013)$ proposed architectural geometry as a design fabrication-aware design knowledge to bridge the gap between design and construction. Tepavčević et al., (2017) established a fabrication-aware design method that can be easily manufactured and assembled. These DfMA-like concepts, including fabrication-aware design and architectural geometry, also enhance manufacturability and assemblability through the early architectural design stage.

The construction industry has benefited from DfMA research and development in other industries. The automotive industry has explored reduction in number of parts in the assembly process. With such reduction comes decline in associated assembly operations, saving parts and operations costs (Boothroyd, 2012). When this strategy was applied in selected Swedish companies, half enjoyed up to a 33\% reduction in development time and cost (Trygg, 1993). In construction, the same logic is applied in MiC, reducing parts in prefabricated modules for assembly. Another commonly adopted DfMA strategy is to establish a concurrent engineering environment. This encourages teamwork between designers, suppliers, manufacturing engineers, and any other relevant representatives in reviewing the current product manufacturing and future product design to increase productivity and reduce lead time in bringing a new product to market (Boothroyd, 2012).

\section{OVERLAPS BETWEEN DFMA AND OTHER CONCEPTS 4.1 DfMA and Buildability}

The concept of buildability can be traced back to the 1980s (Moore, 1996). It is defined by CIRIA (1983) as 'the extent to which the design of a building facilitates ease of construction, subject to the overall requirements for the completed building.' Buildability is measured on a scale from good to bad and is a criterion on which to judge the design of a building project (Wong et al., 2008. Bringing together the technical experience of builders and the design experience of architects at the design stage, it reflects architects' awareness of construction method in the architectural design (Hyde, 1995; Wong et al., 2011). Buildable designs have improved quality and safety performance, as well as higher productivity levels, and mitigate the risks of unforeseen problems (Lam and Wong, 2011). The achievement of good buildability 
depends upon both designers and builders being able to see the whole construction process through each other's eyes.

In design for buildability, external factors such as geotechnical condition, access and circulation at the site, and availability of resources, skills and technology, are firstly considered to determine the most appropriate system to be used (Mbamali et al., 2005). Then, the principle of standardization, simplicity and integration or prefabrication are applied to achieve the desired level of buildability (BCA, 2000; Wong and Lam, 2008). Table 3 presents some example features of these principles. Lam and Wong (2011) further summarize nine factors of buildability: (1) allowing economic use of contractor's resources; (2) enabling design requirements to be easily visualized and coordinated by site staff; (3) enabling contractors to develop and adopt alternative construction details; (4) enabling contractors to overcome restrictive site conditions; (5) enabling standardization and repetition; (6) enabling freedom of choice between prefabricated and onsite works; (7) enabling simplification of construction details in case of non-repetitive elements; (8) minimizing the impact of adverse weather by enabling a more flexible construction program; and (9) allowing design to achieve a safe construction sequence on site.

Table 3. Principles of buildability and their example features

\begin{tabular}{|c|c|}
\hline Principle & Example feature \\
\hline Standardization & $\begin{array}{l}{ }^{\circ} \text { Repetition of grids, floor layouts, component sizes, etc.; } \\
{ }^{\circ} \text { Modularization of grids, concrete beams, slabs, etc.; } \\
{ }^{\circ} \text { Standardization of windows, doors, structural components, services } \\
\text { cores, etc. }\end{array}$ \\
\hline Simplicity & $\begin{array}{l}{ }^{\circ} \text { Flat floor slabs, pre-stressed concrete flat slabs; } \\
{ }^{\circ} \text { Simple connection details; } \\
{ }^{\circ} \text { Simplicity in detailing. }\end{array}$ \\
\hline Integration/Prefabrication & $\begin{array}{l}{ }^{\circ} \text { Precast components such as slabs, columns, beams, façade panels, } \\
\text { window frames, staircases, etc.; } \\
{ }^{\circ} \text { Integrated roof system. }\end{array}$ \\
\hline
\end{tabular}

Sources: Mbamali et al. (2005); Wong and Lam (2008)

There are perceivable similarities and differences between buildability and DfMA. First, both attempt to consider the building/manufacturing processes from the early design stage in order to ease them, as well as improve quality, cost, productivity, and safety performance. Second, both follow the standardization principle for the design of grids, layouts, structural components, doors and windows etc. Third, both encourage integration and prefabrication. However, to meet the requirement of simplicity in buildability, diversity and variability may be sacrificed; DfMA would not change or downgrade the design intentions at the cost of building particularity. Buildability can be enhanced with the implementation of DfMA, prefabrication, and virtual and automated construction technologies. DfMA is the practical implementation and optimization of quantitative and parametric design, which presents all entities in the form of components (Harik and Sahmrani, 2010; Yuan et al., 2018), and can improve buildability with the use of offsite prefabricated standardized components such as façades, bathrooms, and staircases (Gao et al., 2018). DfMA can not only focus on the design evaluation like buildability, but also implement this evaluation in the two links of manufacturing and assembly, which is especially applicable to the rise of off-site manufacturing and on-site assembly.

\subsection{DfMA and Value Management (VM)}

VM aims to an optimal balance of performance, cost, and time through a structured, disciplined, and team-centric problem-solving approach (Kelly et al., 2004). It has been increasingly described as the entire process to improve the value of the project from the concept stage to the 
operation stage (Ashworth and Hogg, 2014). Both VM and DfMA have their origins in the manufacturing industry. Whereas DfMA was popularized in construction only recently, VM has been readily applied to construction for a longer period of time. In common with DfMA, $\mathrm{VM}$ is conducted through the integration and cooperation among multidisciplinary team members.

The differences between VM and DfMA are obvious. Firstly, they have different objectives. DfMA focuses on two main functionality of buildings in terms of manufacturability and assemblability whilst that of VM cares about the optimal balance and solution of all functionality and finance, not just manufacturability and assemblability. Secondly, the methods to achieve their respective goals are different. VM derives its power from being a team-based, process-driven methodology using function analysis to examine and deliver a project at optimized whole life performance and cost without detriment to quality (Male et al., 2007). A range of VM methods, such as pre-workshop info gathering, group workshop tools (e.g. Fast Diagramming, VM / design charrette), post-workshop tools and so on, is applied step by step within the context of changing project environment (Kelly and Male, 2003; Shen and Liu, 2004). In contrast, DfMA uses a series of design strategies under its guidelines and principles to achieve better manufacturability and assemblability. The main idea is to simplify and optimize the building components, connections and processes without damaging or subsiding the originally formulated functionality (Gao et al., 2019; Chen and $\mathrm{Lu}, 2018$ ). For example, applying a digitally-designed set of components across a range of government construction programmes and projects to enhance standardization and productivity. Thus, DfMA dedicates to the improvements in the specific tectonics details of the building, such as component size, building materials and connection method, but VM starts from the perspective of architectural function and adopts a series of management methods.

As an optimal design philosophy, DfMA regarded as a value improvement tool can be adopted by VM. DfMA can earn value in project costs, completion time, accordance to function requirements, satisfaction of post-occupancy evaluation, and ease of maintenance (Omigbodun, 2001; Newton et al., 2018). As a function-review method for optimal design, VM can be applied together with DfMA execution to enhance its cost efficiency, functionality, quality and reduce possible risks. Essentially, these two approaches differ in their focuses and methods on construction because they hold different perspectives. VM represents a project management perspective while DfMA focuses more on a product design perspective. However, they can work together to achieve more efficient construction practices.

\subsection{DfMA and Lean Construction}

Lean construction is 'a method to design production systems to minimize the waste of materials, time and efforts in order to generate the maximum possible amount of value' (Koskela et al., 2002). It is closely linked to VM. Lean principles have their roots in Japanese manufacturing, where the supply chain was planned and optimized to reduce time, cost, and waste. Lean principles were later adapted to the construction industry with the aim of eliminating waste (Koskela, 1992) by considering the particular characteristics of construction works, such as uniqueness, complexity, and 'one-off' project-based production processes. Today, the focal points of lean construction are diverse, including waste elimination, strong user focus, value for money, high-quality management of projects and supply chains, and improved communications (OGC, 2000).

The principles of lean construction and DfMA are interrelated and mutually supportive. On the one hand, DfMA can help lean construction practices focus on reducing waste (Ohno, 1988), also known as 'non-value adding' activities in the lean context (Koskela, 1992). It does so by assisting designers to understand what kinds of inefficient motions and operations are associated with manufacturing and assembly. This is in line with key DfMA principles, i.e., 
minimizing the number of parts, and maximizing ease of handling and assembly (Gerth et al., 2013). Similarly, the work done by Gbadamosi et al. (2018) provides empirical evidence on how DfMA can facilitate the lean process. On the other hand, lean construction thinking can be embedded in DfMA philosophy. For example, Banks et al. (2018) considered lean supply chain management when detailing high-rise building design, while Ramaji et al. (2017) reduced the amount of assembly parts and optimized the geometry design of each part for a dormitory project. DfMA and lean principles can bring common benefits to the AEC industry, aligned to achieve maximum shared value such as reducing construction cost and efforts, and increasing construction productivity (Ogunbiyi et al., 2014).

The two principles, still, are conceptually different with different working scopes and focuses. Lean construction aims to eliminate construction waste, effort, and time by designing a proper production and delivery system over a supply chain. For example, flexible workforce and just-in-time are critical lean principles for preventing overstock and accelerating cash flow. Comparatively, DfMA principles work on improving ease of manufacturing and assembly from the early stage of design (Lam et al., 2009). This involves a series of measures to optimize design, but workforce flexibility and warehousing level are not as heavily involved as in lean construction.

\subsection{DfMA and Prefabrication/MiC}

DfMA is often discussed together with prefabrication or MiC in the literature. In Gibb's (2001) widely accepted taxonomy of prefabrication adoption, Level 0 means a project does not use any form prefabrication at all, e.g. fully cast-in-situ; Level 1: Component and sub-assembly (e.g. lintels); Level 2: Non-volumetric assembly (e.g. 2-dimensional precast concrete wall panels, precast components with no usage space enclosed); Level 3: Volumetric assembly (e.g. volumetric bathrooms, kitchens with usable space enclosed); and Level 4: Modular building (e.g. 3- dimensional modules which form the fabric of the building structure). According to Tatum (1987), prefabrication shifts the conventional cast in-situ, or a part of it, to offsite specialized facilities (e.g., a precast yard) where the raw materials are used to form a component or module of the final installation. Prefabrication can be achieved by carefully designing, manufacturing, transporting and installing the construction components (Mao et al., 2013). MiC represents one specific type where free-standing integrated modules with finishes, fixtures and fittings are manufactured in a prefabrication factory and then transported to site for installation (CIC, 2019). Compared to traditional construction methods, prefabrication/ $\mathrm{MiC}$ is competitive in reducing cost, time, and waste generated in the construction phase (Yuan et al., 2018; Tam et al., 2007).

The resurgence of prefabrication and construction industrialization is a response to increasing housing and construction demand around the globe. It is also an ideal scenario for promotion of DfMA. In this scenario, construction works, traditionally organized as projects, are more akin to production in the manufacturing industry. The design of prefabricated components or integrated modules generally requires more attention to make these components appropriate for offsite manufacturing and on-site assembly. DfMA can address many issues and limitations in the current construction practice. For example, in current designer-centric practice, architects may lack sufficient expertise or interest in considering problems arising at the subsequent manufacture, transportation and assembly of prefabricated components. Such expertise is usually tacit and embedded in the manufacturer's experience. Problems may include insufficient detail in prefabricated components or their connections, inappropriate split of prefabricated components, or complex component design, making reiterative design improvements in the manufacture phase difficult (Yuan et al., 2018; Jensen et al., 2008). In DfMA-oriented design, these problems can be addressed by involving manufacturers and technicians in the upfront stage (i.e., design) and carefully considering problems in subsequent 
manufacture and assembly. Therefore, DfMA is considered as one of the most important steps in prefabrication/MIC (Jensen et al., 2008).

\section{PROSPECTS AND CHALLENGES OF DFMA}

\subsection{Prospects of DfMA}

DfMA is expected to have a wide range of applications, from one-off small-scale to large-scale construction projects, and can benefit both cast in-situ and prefabricated construction methods. However, its most widespread adoption is foreseen in prefabrication/MiC projects. Some empirical studies have begun to investigate the process of using DfMA guidelines for prefabrication/MiC. DfMA-oriented designs have been reported in various types of prefabrication/MiC projects around the globe. DfMA has also been applied to prefabrication/ $\mathrm{MiC}$ using advanced information technologies such BIM (Yuan et al., 2018). Although focusing on different scenarios, these studies share some common practices in applying DfMA guidelines, e.g., forming a DfMA-oriented design team by including architects, engineers, manufacturers and contractors, identifying design problems that need to be tackled for ease of manufacture and assembly, and optimizing building design using DfMA principles.

The popularity of DfMA will increase with increasing demand for more integrated methods of project delivery and value creation. VM and integrated project delivery (IPD) seek to align the objectives and practices of stakeholders so that their insights can be harnessed to optimize project performance. The collaboration of stakeholders, such as designers, engineers, suppliers, and contractors at the early design stage means that more detailed information becomes available earlier than in the traditional design process. Such collaboration thus can help identify and address potential risks in the manufacturing and construction stages based on DfMA principles.

Another trend is the integration of DfMA and virtual design and construction (VDC) technologies like BIM. A building information model is the digital representation of a building with all building components represented by parametric objects (Eastman et al., 2011). BIM can facilitate DfMA implementation from two perspectives. First, DfMA requires an analysis platform for identifying opportunities for improving manufacturing and assembly processes through the design. BIM provides such a platform because BIM objects can have rich information on the actual building components. The information can be used to analyze how the components will be produced and constructed, and whether DfMA principles can be applied to make the design more appropriate for production and construction. Secondly, BIM enables a seamless collaboration environment. Designers, engineers, suppliers, and constructors can use the digital model to exchange ideas and share knowledge with each other (Zhong et al., 2017; Chen et al., 2017). After the design is consolidated, the BIM model can be directly sent to the suppliers or manufacturers for mass production.

To sum up, DfMA is expected to be adopted in the AEC industry in order to improve the efficiency and effectiveness of the project delivery. Smooth deployment of DfMA principles in construction projects can be achieved with the support of new project management and delivery methods (e.g., IPD) and VDC technologies (e.g., BIM).

\subsection{Challenges Ahead}

The first challenge facing DfMA application in construction is lack of a suitable ecosystem that enables its widespread adoption. An ecosystem includes guidelines, standards, and affordable technologies. Guidelines and standards are important for stakeholders, especially those with less experience, to govern its procedures of DfMA applications. Additionally, a report published by O'Rourke (2013) indicates that the gross capital cost of DfMA assembly, at the early adoption stage, is comparable to that of traditional construction methods. However, if new 
technologies were required to support DfMA applications, extra investment might be needed, making DfMA less competitive. These challenges necessitate a robust ecosystem enabling wide acceptance of DfMA.

Another challenge is associated with the new processes brought about by DfMA applications. DfMA requires stakeholders to shift their paradigm from conventional means of design, production, and construction (Chen and Lu, 2018; Yuan et al., 2018; Gao et al., 2019). However, it is not always easy for stakeholders to adjust to new processes. For example, designers might not be willing to accept manufacturing or construction input in their designs. The resistance to change could be considerably overwhelming. Therefore, additional efforts are necessary to manage the change, for instance, by increasing stakeholder awareness of the advantages of DfMA.

Furthermore, there are few cases of DfMA application in actual projects, perhaps owing to insufficient hands-on training and re-training arranged for different stakeholders to implement DfMA. Some stakeholders might choose to wait and see whether competitors implementing DfMA can receive actual benefits. Currently, a few large companies have begun to use DfMA in their projects. More successful DfMA application cases will encourage the diffusion of DfMA in the AEC industry.

\section{CONCLUSION}

Originating from production industries, DfMA has been hyped as a panacea for chronic problems in the AEC industry such as high cost, long delivery time, and low productivity. This paper aims to demystify the concept in AEC, which is well known for its project-based nature. Many features of AEC, e.g., bespoke requirements, 'one-off' endeavors, contextual embeddedness, and prolonged manufacturing and assembly lines seem to have stifled the widespread application of DfMA. Our review of the historical development of DfMA, reasons for its popularization, and its status quo development in construction, reveals that DfMA as a philosophy is hardly new in construction, and the empirical implementation of many DfMA guidelines has begun in the AEC industry.

A deeper look at DfMA and its similar concepts including buildability evaluation, value management, lean construction, and prefabrication/offsite construction, reveals that the DfMA philosophy is reflected in various construction practices. It further substantiated the above argument that DfMA is not entirely new in construction. Adjusting the metaphor used in our original question, however, we would argue that DfMA is a 'new cocktail in a new bottle'. Bearing a set of well-developed DfMA guidelines, it embraces a variety of tools and techniques, such as BIM, VDC, MiC, prefabrication, IoTs, and smart construction, to help designers optimize design, manufacturing, and assembly. It is also compatible with prevailing concepts in construction, such as integrated procurement models (e.g., design and building, IPD), preoccupational evaluation, value management, and lean construction to enhance value in the AEC industry.

Nevertheless, DfMA in construction is still in its infancy. Current research and practice of DfMA in the construction industry largely follow some guidance and strategies of the manufacturing industry, without fully considering their differences. Some of these strategies, frameworks, and applications are inadequate for the construction industry, especially in projects with varying degrees of prefabrication. Practitioners need to be inspired and encouraged by successful DfMA examples, for which a sharing platform across the globe is required. The limited examples reported in the literature give the impression that DfMA serves prefabrication/MiC only. More research studies on its applications in cast in-situ, or intermediate prefabrication construction are recommended. In addition to encouraging DfMA frameworks and blueprints already developed in various countries, operable strategies are needed to guide interested stakeholders in implementing DfMA in their respective businesses. 


\section{REFERENCES}

Alarcón, L. (1997). Lean construction. CRC Press.

Ashley, S. (1995). Cutting costs and time with DfMA. Mechanical Engineering, 117(3), 74.

Ashworth, A., \& Hogg, K. (2014). Added value in design and construction. Routledge.

Baloi, D., \& Price, A. D. (2003). Modelling global risk factors affecting construction cost performance. International journal of project management, 21(4), 261-269.

Balfour Beatty (2018). Streamlined construction: Seven steps to offsite and modular building.

Banks, C., Kotecha, R., Curtis, J., Dee, C., Pitt, N., \& Papworth, R. (2018). Enhancing highrise residential construction through design for manufacture and assembly-a UK case study. Proceedings of the Institution of Civil Engineers-Management, Procurement and Law, 171(4), 164-175.

Başarır, B., \& Altun, C. M. (2018). A Redesign Procedure to Manufacture Adaptive Façades with Standard Products. Journal of Facade Design and Engineering, 6(3), 77-100.

BCA (2000). Code of practice on buildable design. Building and Construction Authority, Singapore.

BCA (2016). BIM for DfMA Essential Guide. Building and Construction Authority, Singapore.

Bogue, R. (2012). Design for manufacture and assembly: background, capabilities and applications. Assembly Automation, 32(2), 112-118.

Boothroyd, G. (2005). Assembly automation and product design. CRC Press.

Boothroyd, G (2012). Design For Manufacture And Assembly: The Boothroyd-Dewhurst Experience. In Eastman, C. M. (Ed.). Design for X: concurrent engineering imperatives. (pp. 19-40). Springer Science \& Business Media.

Bridgewater, C. (1993). Principles of design for automation applied to construction tasks. Automation in Construction, 2(1), 57-64.

Chen, K., \& Lu, W. (2018). Design for manufacture and assembly oriented design approach to a curtain wall system: A case study of a commercial building in Wuhan, China. Sustainability, 10(7), 2211.

Chen, K., Xu, G., Xue, F., Zhong, R. Y., Liu, D., \& Lu, W. (2017). A physical Internetenabled BIM system for prefabricated construction. International Journal of Computer Integrated Manufacturing. 31(4-5), https://bit.ly/2PLRAM3.

Construction Industry Council (CIC) (2019). What is CIC? Available at https://bit.ly/2vBWLVI.

Construction Industry Research and Information Association (CIRIA) (1983). Buildability: an assessment. London: CIRIA.

Di Giuda, G. M., Giana, P. E., Masera, G., Seghezzi, E., \& Villa, V. (2019). A BIM-based approach to façade cladding optimization: geometrical, economic, and production-control in a DfMA perspective. In 2019 European Conference on Computing in Construction (Vol. 1, pp. 324-331). European Council on Computing in Construction.

Eastman, C., Teicholz, P., Sacks, R., \& Liston, K. (2011). BIM handbook: A guide to building information modeling for owners, managers, designers, engineers and contractors. John Wiley \& Sons.

Eastman, C. M. (2012). Design for X: concurrent engineering imperatives. Springer Science \& Business Media.

Emmatty, F. J., \& Sarmah, S. P. (2012). Modular product development through platform-based design and DfMA. Journal of Engineering Design, 23(9), 696-714.

Fox, S., Marsh, L., \& Cockerham, G. (2001). Design for manufacture: a strategy for successful application to buildings. Construction Management and Economics, 19(5), 493-502.

Gao, S., Low, S. P., \& Nair, K. (2018). Design for manufacturing and assembly (DfMA): a preliminary study of factors influencing its adoption in Singapore. Architectural Engineering and Design Management, 14(6), 440-456. 
Gao, S., Jin, R., \& Lu, W. (2019). Design for manufacture and assembly in construction: a review. Building Research \& Information, 1-13.

Gatenby, D. A., \& Foo, G. (1990). Design for X (DFX): Key to competitive, profitable products. AT\&T Technical Journal, 69(3), 2-13.

Gbadamosi, A. Q., Mahamadu, A. M., Manu, P., Akinade, O., Sierra, F., Lam, T. T., \& Alzaatreh, A. (2018). A BIM based approach for optimization of construction and assembly through material selection. In: Skibniewski, M. and Hajdu, M., eds. Creative Construction Conference 2018 (CCC 2018), Ljubljana, Slovenia, 30 June - 3 July 2018.

Gerth, R., Boqvist, A., Bjelkemyr, M., \& Lindberg, B. (2013). Design for construction: utilizing production experiences in development. Construction Management and Economics, $31(2), 135-150$.

Gibb, A. G. (2001). Standardization and pre-assembly-distinguishing myth from reality using case study research. Construction Management and Economics, 19(3), 307-315.

Harik, R. F., \& Sahmrani, N. (2010). DFMA+, a quantitative DFMA methodology. ComputerAided Design and Applications, 7(5), 701-709.

Huang, G. Q. (2012). Introduction. In Eastman, C. M. (Ed.). Design for X: concurrent engineering imperatives. (1-18). Springer Science \& Business Media.

Hyde, R. (1995). Buildability as a design concept for architects: a case study of laboratory buildings. Engineering, Construction and Architectural Management, 2(1), 45-56.

Infrastructure and Projects Authority (2018). National infrastructure and construction pipeline. Available at https://bit.ly/2QoJxYn.

Jensen, P., Olofsson, T., Sandberg, M., \& Malmgren, L. (2008). Reducing complexity of customized prefabricated buildings through modularization and IT support. In International Conference on Information Technology in Construction: 15/07/200817/07/2008 (429-437). Universidad de Talca.

Kao, C. C., Green, S. D., \& Larsen, G. D. (2009). Emergent discourses of construction competitiveness: localized learning and embeddedness. Construction Management and Economics, 27(10), 1005-1017.

Kelly, J., Male, S., Graham, D., Male, S., \& Graham, D. (2004). Value management of Construction Projects (pp. 9-19). Oxford: Blackwell Science.

Kelly, J., \& Male, S. (2003). Value management in design and construction. Routledge.

Kim, M. K., McGovern, S., Belsky, M., Middleton, C., \& Brilakis, I. (2016). A suitability analysis of precast components for standardized bridge construction in the United Kingdom. Procedia Engineering, 164, 188-195.

Koskela, L. (1992). Application of the new production philosophy to construction (Vol. 72). Stanford: Stanford University.

Koskela, L., Howell, G., Ballard, G., \& Tommelein, I. (2002). The foundations of lean construction. Design and construction: Building in Value, 291, 211-226.

Kuo, T. C., Huang, S. H., \& Zhang, H. C. (2001). Design for manufacture and design for ' $X$ ': concepts, applications, and perspectives. Computers \& Industrial Engineering, 41(3), 241-260.

Lam, P. T., \& Wong, F. W. (2009). Improving building project performance: how buildability benchmarking can help. Construction Management and Economics, 27(1), 41-52.

Lam, P. T., \& Wong, F. W. (2011). A comparative study of buildability perspectives between clients, consultants and contractors. Construction Innovation, 11(3), 305-320.

Lecy, J. D., \& Beatty, K. E. (2012). Representative literature reviews using constrained snowball sampling and citation network analysis. Available at SSRN 1992601.

Lu, W., Chen, K., Xue, F., \& Pan, W. (2018). Searching for an optimal level of prefabrication in construction: An analytical framework. Journal of Cleaner Production, 201, 236-245. 
Machado, M., Underwood, J., \& Fleming, A. (2016). Implementing BIM to streamline a design, manufacture, and fitting workflow: a case study on a fit-out SME in the UK. International Journal of 3-D Information Modeling (IJ3DIM), 5(3), 31-46.

Male, S., Kelly, J., Gronqvist, M., \& Graham, D. (2007). Managing value as a management style for projects. International Journal of Project Management, 25(2), 107-114.

Mao, C., Shen, Q., Shen, L., \& Tang, L. (2013). Comparative study of greenhouse gas emissions between offsite prefabrication and conventional construction methods: Two case studies of residential projects. Energy and Buildings, 66, 165-176.

Maskell, B. H. (1991). Performance measurement for world class manufacturing: A model for American companies. CRC press.

Mbamali, I., Aiyetan, O. A., \& Kehinde, J. O. (2005). Building design for buildability: an investigation of the current practice in Nigeria. Building and Environment, 40(9), 12671274.

Montali, J., Overend, M., Pelken, P. M., \& Sauchelli, M. (2018). Knowledge-Based Engineering in the design for manufacture of prefabricated façades: current gaps and future trends. Architectural Engineering and Design Management, 14(1-2), 78-94.

Montali, J., Sauchelli, M., Jin, Q., \& Overend, M. (2019). Knowledge-rich optimisation of prefabricated façades to support conceptual design. Automation in Construction, 97, 192204.

Moore, D. (1996). Buildability assessment and the development of an automated design aid for managing the transfer of construction process knowledge. Engineering, Construction and Architectural Management, 3(1/2), 29-46.

Newton, C., Backhouse, S., Aibinu, A., Cleveland, B., Crawford, R., Holzer, D., ... \& Kvan, T. (2018). Plug n Play: Future Prefab for Smart Green Schools. Buildings, 8(7), 88.

OGC (2000), Achieving Sustainability in Construction Procurement, Produced by the Sustainability Action Group of the Government Construction Clients' Panel (GCCP), available at: Www.ogc.gov.uk/documents/Sustainability_in_Construction_ Procurement.pdf

Ogunbiyi, O., Goulding, J. S., \& Oladapo, A. (2014). An empirical study of the impact of lean construction techniques on sustainable construction in the UK. Construction Innovation, 14(1), 88-107.

Ohno, T. (1988). Toyota production system: beyond large-scale production. crc Press.

Omigbodun, A. (2001). Value engineering and optimal building projects. Journal of Architectural Engineering, 7(2), 40-43.

Orlowski, K., Shanaka, K., \& Mendis, P. (2018). Design and Development of Weatherproof Seals for Prefabricated Construction: A Methodological Approach. Buildings, 8(9), 117.

O'Rourke, L. (2013). The future of DfMA is the future of construction. Engineering Excellence Journal (2013), 77.

Pearce, D. W. (2003). The Social and Economic Value of Construction: The Construction Industry's Contribution to Sustainable Development, 2003. Construction Industry Research and Innovation Strategy Panel.

Peterseim, J. H., White, S., \& Hellwig, U. (2016). Novel solar tower structure to lower plant cost and construction risk. In AIP Conference Proceedings, 1734(1), p. 070025). AIP Publishing.

Pottman, H. (2009). Geometry and new and future spatial patterns. Architectural Design, 79(6), 60-65.

Pottmann, H. (2010). Architectural geometry as design knowledge. Architectural Design, 80(4), $72-77$.

Pottmann, H. (2013). Architectural geometry and fabrication-aware design. Nexus Network Journal, 15(2), 195-208. 
Ramaji, I. J., Memari, A. M., \& Messner, J. I. (2017). Product-oriented information delivery framework for multistory modular building projects. Journal of Computing in Civil Engineering, 31(4), 04017001.

Rawlinson, J. G. (2017). Creative Thinking and Brainstorming. Routledge.

Royal Institute of British Architects. (2013), RIBA Plan of Work 2013. RIBA Publishing.

Shen, Q., \& Liu, G. (2004). Applications of value management in the construction industry in China. Engineering, Construction and Architectural Management, 11(1), 9-19.

Swift, K. G, \& Brown, N. J. (2013). Implementation strategies for design for manufacture methodologies, Proceedings of the Institution of Mechanical Engineers. Part B: Journal of Engineering Manufacture, 217(6), 827-833.

Tam, V. W., Tam, C. M., Zeng, S. X., \& Ng, W. C. (2007). Towards adoption of prefabrication in construction. Building and Environment, 42(10), 3642-3654.

Tatum, C. B., Vanegas, J. A., \& Williams, J. M. (1987). Constructability improvement using prefabrication, preassembly, and modularization. Austin, TX, USA: Bureau of Engineering Research, University of Texas at Austin.

Tepavčević, B., Stojaković, V., Mitov, D., Bajšanski, I., \& Jovanović, M. (2017). Design to fabrication method of thin shell structures based on a friction-fit connection system. Automation in Construction, 84, 207-213.

The Economist (2017). The construction industry's productivity problem [Electronic Version]. The Economist. https://econ.st/2RzMkLW, retrieved on April 03, 2019.

The Government of Hong Kong SAR Development Bureau. (2018). Construction 2.0. Available at https://www.hkc2.hk/booklet/Construction-2-0-en.pdf

Tommelein, I. D. (1998). Pull-driven scheduling for pipe-spool installation: Simulation of lean construction technique. Journal of Construction Engineering and Management, 124(4), 279-288.

Trygg, L. (1993). Concurrent engineering practices in selected Swedish companies: a movement or an activity of the few?. Journal of Product Innovation Management, 10(5), 403-415.

Wong, F. W., \& Lam, P. T. (2008). Benchmarking of buildability and construction performance in Singapore: is there a case for Hong Kong?. International Journal of Construction Management, 8(1), 1-27.

Wang, H.D. Lu, W., Sönderland, J., \& Chen, K. (2018). The interplay between formal and informal institutions in projects: A social network analysis. Project Management Journal, 49(4) 20-35.

Yuan, Z., Sun, C., \& Wang, Y. (2018). Design for Manufacture and Assembly-oriented parametric design of prefabricated buildings. Automation in Construction, 88, 13-22.

Zhong, R., Peng, Y., Xue, F., Fang, J., Zou, W., Luo, H., Ng. S.T., Lu, W.S., Shen, Q.P., and Huang, G.Q. (2017). Prefabricated construction enabled by the Internet-ofThings. Automation in Construction, 76(4), 59-70. 